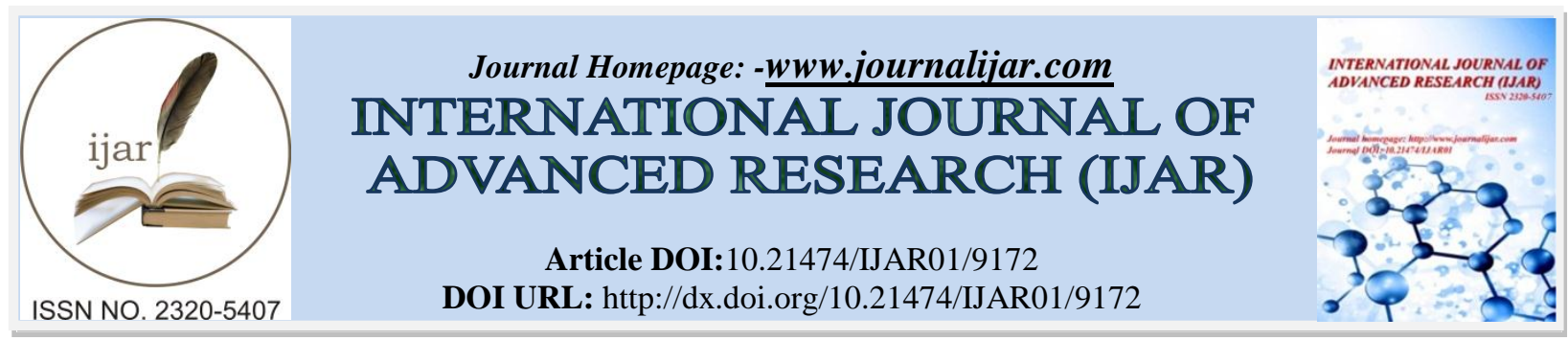

RESEARCH ARTICLE

\title{
A COMPARATIVE STUDY OF EDUCATION IN TRIBAL AND NON-TRIBAL WOMEN IN WEST BENGAL.
}

1. Principal, Hijli College, Kharagpur.

\section{Dr. Asis Kumar Dandapat ${ }^{1}$ and Sourav Manna ${ }^{2}$.}

2. Research scholar in Jharkhand Rai University, Ranchi.

\section{Manuscript Info}

Manuscript History

Received: 24 March 2019

Final Accepted: 26 April 2019

Published: May 2019

\section{Abstract}

This paper examines access a comparative study of Education in tribal and non-tribal women in W.B. during the census report 2011 under Paschim Medinipur, Puruliya and Jalpaiguri. To be more specific the tribal and non-tribal women's education and literacy are compared and justified authentically.

Copy Right, IJAR, 2019,. All rights reserved.

\section{Introduction}

Education system should make an individual better suited to the needs of the ever changing dynamic world. The changes in the educational system should reduce the social gaps by enabling proper recognition to whatever extent one is able to pursue or acquire a skill. The tribal community all over India have been subjected to various forms of deprivation such as alienation from land and other resources. Especially the tribal women though they are away from the main stream of national life, but they are not kept away from the impact of socio - economic changes effecting the society in general. In this process of change, the tribal woman is forced to adhere to certain norms which may even take away her freedom, her control over the traditional productive system, her house, family and children and even her own life. The fact remains that a large number of tribal and non tribal women have missed education at different stages and in order to empower them there is a great need of providing opportunities so as to enable them to assume leadership qualities for economic self-reliance and even social transformation. It is often alleged that the level of aspiration of these women as a group is low and they are quite satisfied with what they are and with what they have. It is most often not true only to womenfolk but to everyone who feels helpless and frustrated. However in order to develop and raise their level of aspiration, adequate educational opportunities are to be provided so that they get motivated to participate, support and also ultimately learn to initiate their own programs of development. Therefore, in this paper an attempt has been made to analyze the present status of educational facilities availed by tribal and non tribal women. A tribal and non tribal woman occupies an important place in the Socio-economic and political structure of her society. They exercise free and firm hand in all aspects related to their social and economic life.

\section{Statement of the problem:}

The statement of the present study is: "A comparative study of education in tribal and non tribal women in W.B. and its impact and development of society"

\section{Objectives of the study:}

The study has formulated the following objectives:

1. To study social group percentage of population.

2. To study social group percentage of literates. 
3. To study gender wise social group percentage of literates.

4. To study gender wise social group percentage of literates ST.

5. To study gender wise social group of percentage in non-tribal.

6. To study gender wise social group of percentage in tribal.

7. To study feminine wise social group of tribal and non-tribal.

\section{Review of Literature:}

Margaret Mead (1943) defines, education as the cultural process, the way in which each new born human infant is transformed into a full member of a specific human society. Both these definitions indicate one aspect socialization or education is a cultural process in which inculcation of norms, values attitudes morals and skills, the members of the society ensures continuity in each generation with regard to various aspects of society. Socialization in a traditional society stabilizes social norms and values. It is essentially a conservative and culture transmitted process. elementary Indian education never brought any radical innovation of values. However, with the changing world, the concept of education is experiencing a complete term evaluation. Today education a powerful agent of social change. It unlocks the door to modernization. It also paves a sure road to economic modernization and progress. kshatriya,( 1989) The study of fertility on the bases ofgeographical data collected from 792 households of Muria, Mariya, Bhattra and Halbatribes of Bastar district in Madhya Pradesh. Show of that the mean number of children ever born to women of these tribes is 5.64, 6.00, 5.95and 5.89 and these values are higher than the rural non tribes. Sharma, (1999) it was observed that the contraceptive acceptance among Gond tribe is very low and it was attributed due to the factors like religious attitude of people, agricultural system of economy, illiteracy and high death rate. (Mehrotra, (2004) to assess women's autonomy, in NFHS-2 women were asked about their participation in households' decision making process, freedom of movement, and access to money that they could spend as per wishes. The certain basic, social, economic and political issues which create difficulties in understanding tribal women in social science, literature, policy making and their implementation. The relationship of tribal women with the women's movement in India, and the changing economic scenario is being problematical.

\section{Significance of the study:}

The education level of the tribal population is low and formal education has made very little impact on tribal groups. The level of literacy among the tribals in most states in India is very low. Reservation policy of the Government has made some changes in the educational status. One of the main reasons for low level of literacy is their assigning relatively less significance on formal schooling. The school curriculum and education system do not create much interest in them, rather a much more practical based curriculum would be helpful for them. Moreover, since the tribes live in poverty they do not like to send their children to schools as they are considered to be extra helping hands for generating income. Work participation rate among scheduled tribe women were higher in percentage as compared to others. Poor economic condition has a direct bearing on the degree of participation. Scheduled tribe workers are engaged in agricultural sector and in non gainful occupations. Considering the education, economic and health of the tribal women, their positions were not at all satisfactory. Most of the tribal women work outside their homes and are engaged in various activities. They work in order to earn money for their family. The women's work involves daily labour, agricultural work. Even young children and girls go for work along with their mothers. Most of the time they do not go to school regularly or become drop outs from school. Even the parents in very poor families don't always want to send the children to school because then their helping hands in work would be reduced. Effect of patriarchy could be strongly seen in most tribal groups and so whatever money women get from their work they give it to their husband and the husband very often spends the money on activities like drinking. Household works are done by the female members of the family. Household work involves cooking, cleaning, washing utensils and clothes, collecting fuel for cooking. The young girls who are studying in primary level in schools hardly learn anything in school and they don't study at home also. The government has announced free and compulsory education to all children up to the age of 14 years, which nowadays encourage parents to send their children to schools with the hope that if their children receive proper education, then their conditions will improve. The children are given free school uniforms, books and mid day meals. However, the girls don't continue school at a stretch. Sometimes they go to school, some other times they do not go to school and stay at home and go to work with their mothers and help theirmothers at household work. As a result, they tend to forget what they have learned in school. After the girl child attainsteenage the parents stop sending them to schools. Lack of awareness about nutritional requirements mostly leaves the tribal women weak, anaemicand they suffer from various diseases. During pregnancy, special attention is required to be given to women otherwise thatwill affect the health of both the mother and child.Educational level, employment status, health status and decision making ability helps to measure the status of non tribal women in society. Their education has to be channelized to employment opportunities. This 
in turn, will increase the decision making ability of women. and to communicate with other family members and to be able to convince them indicates a decision making ability of women. When the decision making ability is higher, women can have a higher statusin the household. The study is important to find out impact and educational development of tribal and non tribal women

\section{Operational definitions:}

i)Comparative study: A comparative study is a study in which a participant is randomly assigned to one of two or more different treatment groups for purposes of comparing the effects of the treatments.

ii) Tribal women: The tribal women are a collection of families or group of families bearing a common name, member of which occupy the same territory, speak the same language and observe certain taboos regarding marriage, profession of occupation and have developed value assessed system of reciprocity and mutuality of obligations".

iii) Non tribal women: The non tribal women have lower and upper level of education, status of women and exposure to mass media the characteristic that effect. They also have middle age of marriage and family planning

\section{Design of study:}

The State WB is located between $22^{`} \mathrm{~N}$ to $27^{`} \mathrm{~N}$ and $86 \mathrm{E}$ to $90^{\circ} \mathrm{E}$. The state of WB has been divided into three divisions .These are Presidency, Burdwan, Jalpaiguri. Presidency division comprises Howrah, Kolkata Murshidabaqd, Nadia, North 24 Parganas and South 24 Parganas districts. The Burdwan division comprises Bankura, Birbhum, Burdwan, Hoogly, Purulia, Paschim Medinipur, Purba Medinipur districts and Jalpaiguri division comprises Alipurduar, Jalpaiguri Darjeeling, Kochbihar, Maldaha, Uttardinajpur, Dakshin Dinajpur districts. In WB the total number of villages consists of 42400.In which 42000 villages are populated, whereas the number of De-populated villages are 400.Now for the purpose of the study 3 districts i.e. Paschim Medinipur, Puruliya, Jalpaiguri are selected as per the highest rate of population and 10 blocks form the tribal and the non-tribal were selected from each 3 districts i.e. 10x3=30 - 10 blocks were taken out of 13 blocks under puruliya, 10 blocks out of 29 blocks under paschim Medinipur and 10 blocks out of 13 blocks under Jalapaiguri. 10 villages of tribal (female) and non-tribal (female) were selected form 10 blocks of each districts among which 4 ( 2 tribal women and 2 non-tribal women) were chosen from 10 villages of 10 blocks of 3 districts i.e. 300x4=1200 (tribal and non-tribal women) villages in total trhough stratified samply method.

\section{Analysis and Interpretation of Data:}

Table No. - 1: Social group percentage of population in Paschim Medinipur, Puruliya and Jalpaiguri Districts.

\begin{tabular}{|l|l|l|l|l|}
\hline \multirow{2}{*}{ SI no. } & Social group & Percentage in population of Districts & \multicolumn{2}{|l|}{} \\
\cline { 2 - 5 } & & Paschim Medinipur & Puruliya & 81.11 \\
\hline 1. & Non-ST & 85.12 & 81.55 & 18.89 \\
\hline 2. & ST & 14.88 & 18.45 & \\
\hline
\end{tabular}

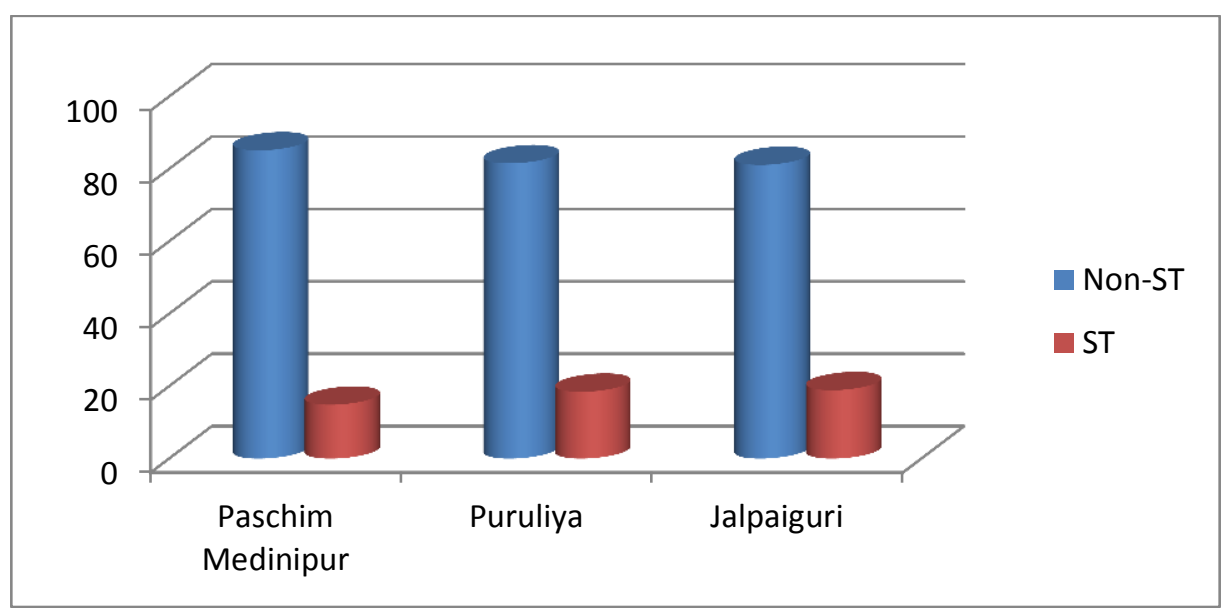

It is evident from table no 01. that social group percentage of population of non ST under Paschim Medinipur $(85.12 \%)$ is greater than Puruliya $(81.55 \%)$ and Jalpaiguri $(81.11 \%)$ where social group percentage of ST' under 
Paschim Medinipur (14.88\%) is lesser than Puruliya (18.45\%) and Jalpaiguri (18.89\%). If we want to see the percentage of literates of that districts we should follow the next diagram.

Table No. - 2: Social group percentage of literates in Paschim Medinipur, Puruliya, Jalpaiguri districts.

\begin{tabular}{|l|l|l|l|l|}
\hline \multirow{2}{*}{ SI no. } & Social group & Percentage of literates & Jalpaiguri \\
\cline { 2 - 5 } & & Paschim Medinipur & Puruliya & 85.96 \\
\hline 1. & Non-ST & 88.88 & 84.62 & 14.96 \\
\hline 2. & ST & 11.12 & 15.38 & \\
\hline
\end{tabular}

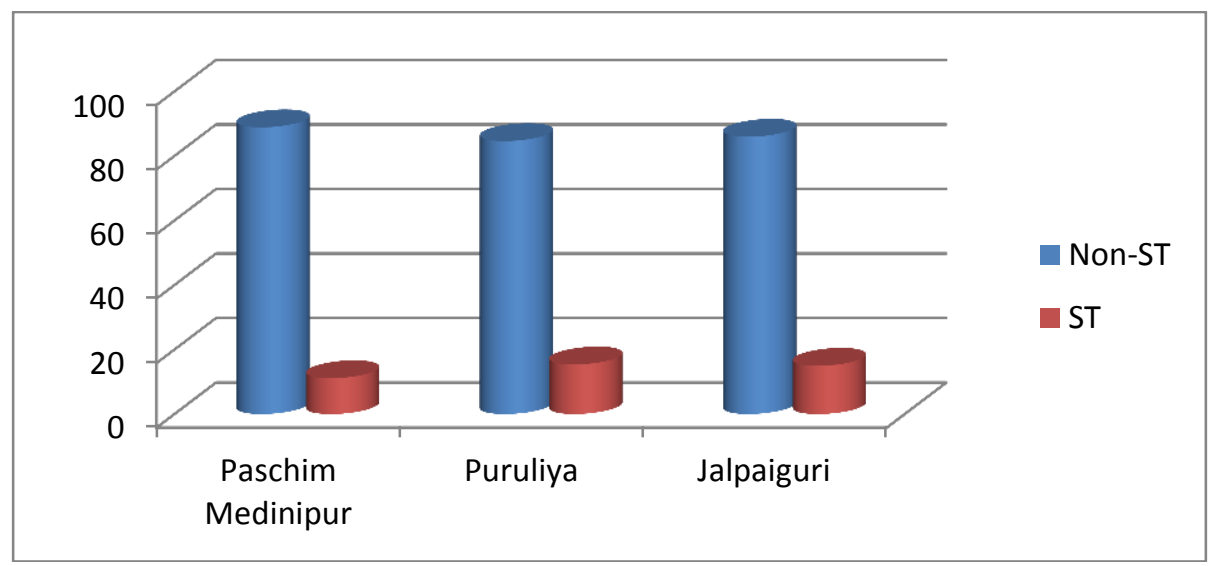

It has been shown from table no 02. that social group percentage of literates of non ST' under Paschim Medinipur $(88.88 \%)$ is greater than Jalpaiguri $(85.96 \%)$ and Puruliya $(84.62 \%)$ where as social group percentage of literates of ST' under Paschim Medinipur (11.12\%) is lesser than Jalpaiguri (14.96\%) and Puruliya (15.38\%). Gender wise social group literates, is follow by to the next table.

Table No. - 3: Gender wise social group of literates under Paschim Medinipur, Puruliya, Jalpaiguri districts.

\begin{tabular}{|l|l|l|l|l|}
\hline \multirow{2}{*}{ SI no. } & Social group & Population in \% & Jalpaiguri \\
\cline { 2 - 5 } & & Paschim Medinipur & 61.97 & 56.05 \\
\hline 1. & Male & 55.84 & 38.03 & 43.95 \\
\hline 2. & Female & 44.16 & & \\
\hline
\end{tabular}

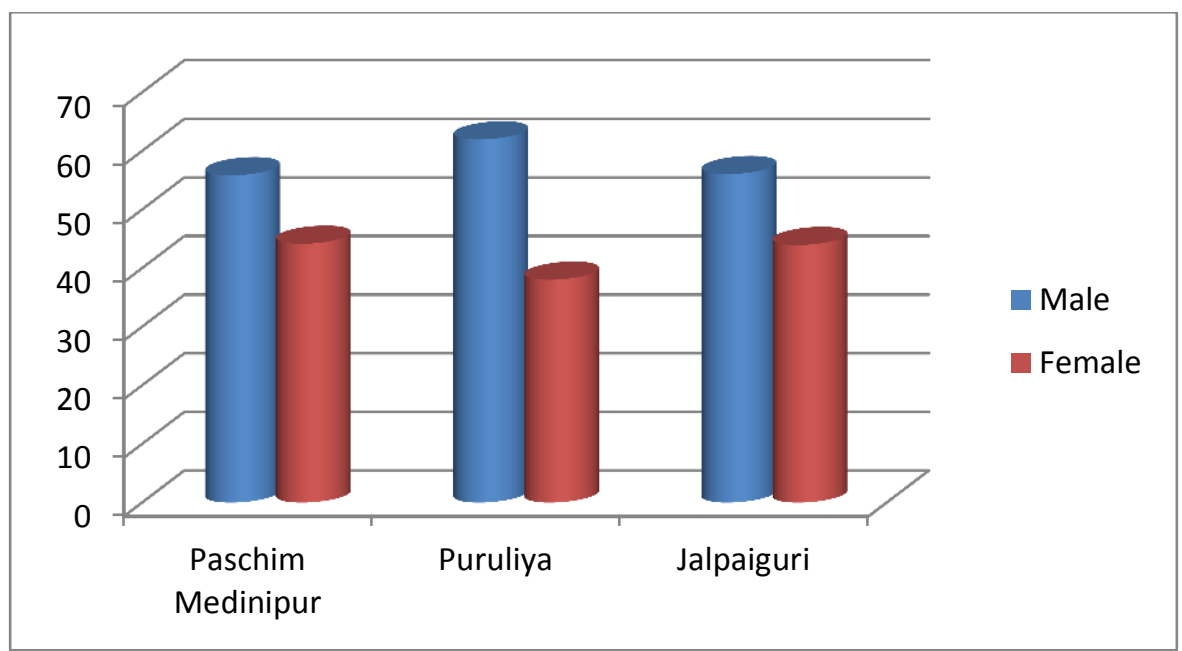

It is evident from table no 03. that gender wise social group of 'literates Male of non ST' under puruliya (61.97\%) is greater than Paschim Medinipur (55.84\%) and Jalpaiguri (56.05\%) where 'literates Female non ST' under puruliya (38.03\%) is lesser than Paschim Medinipur (44.16\%) and Jalpaiguri (43.95\%). Gender wise social group of percentage in non-tribal, has been following to next diagram. 
Table No. - 4: Gender wise social group of percentage in non-tribal under Paschim Medinipur, puruliya, jalpaiguri districts.

\begin{tabular}{|l|l|l|l|l|}
\hline \multirow{2}{*}{ SI no. } & $\begin{array}{l}\text { Gender wise social } \\
\text { group }\end{array}$ & Percentage in non-tribal \\
\cline { 2 - 5 } & & Paschim Medinipur & Puruliya & Jalpaiguri \\
\hline 1. & Male & 51.02 & 51.27 & 51.48 \\
\hline 2. & Female & 48.98 & 48.73 & 48.52 \\
\hline
\end{tabular}

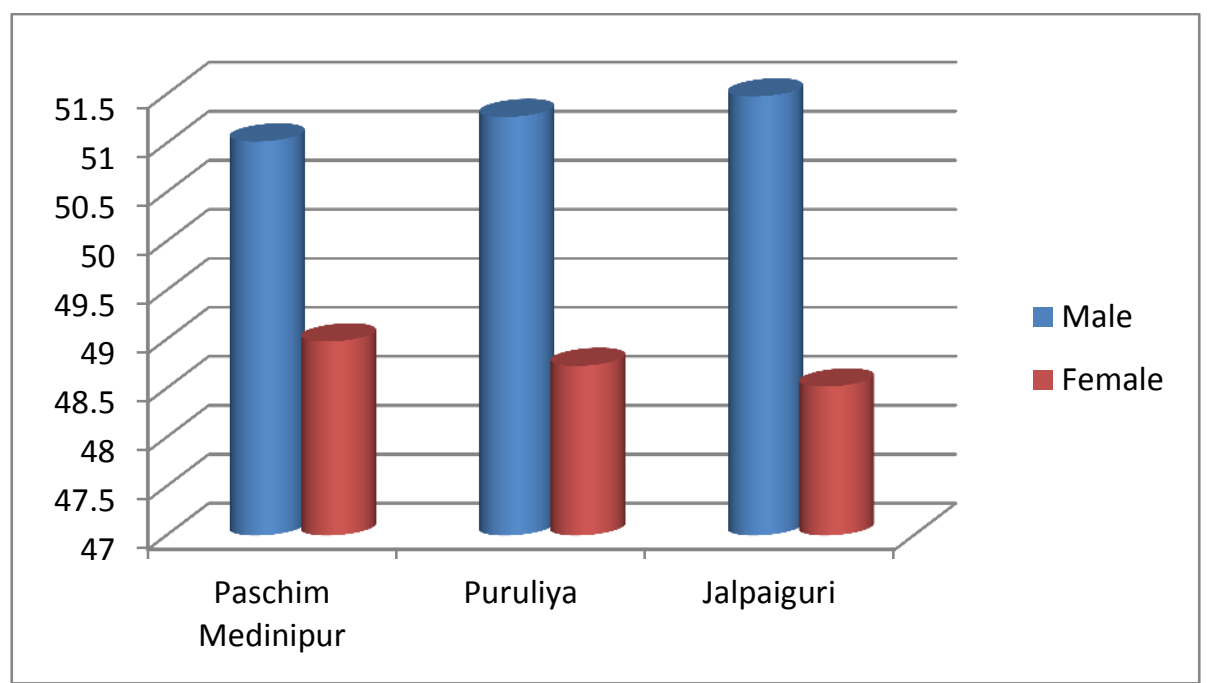

It is evident from table no 05. that gender wise social group of 'Male non Tribal' under Paschim Medinipur $(51.02 \%)$, Puruliya $(51.27 \%)$ and Jalpaiguri $(51.48 \%)$ is same cross the line where gender wise social group of 'Female Non Tribal' remains under Paschim Medinpur (48.98\%), Puruliya (48.73\%) and Jalpaiguri (48.52\%) is same cross the line. Gender wise social group of literates ST, is followed next diagram.

Table No. - 5: Gender wise social group of literates ST under Paschim Medinipur, Puruliya \& Jalpaiguri districts.

\begin{tabular}{|l|l|l|l|l|}
\hline \multirow{2}{*}{ SI no. } & $\begin{array}{l}\text { Gender wise social } \\
\text { group }\end{array}$ & Literates ST in \% \\
\cline { 2 - 5 } & & Paschim Medinipur & Puruliya & Jalpaiguri \\
\hline 1. & Male & 59.52 & 63.22 & 57.74 \\
\hline 2. & Female & 40.48 & 36.78 & 42.26 \\
\hline
\end{tabular}

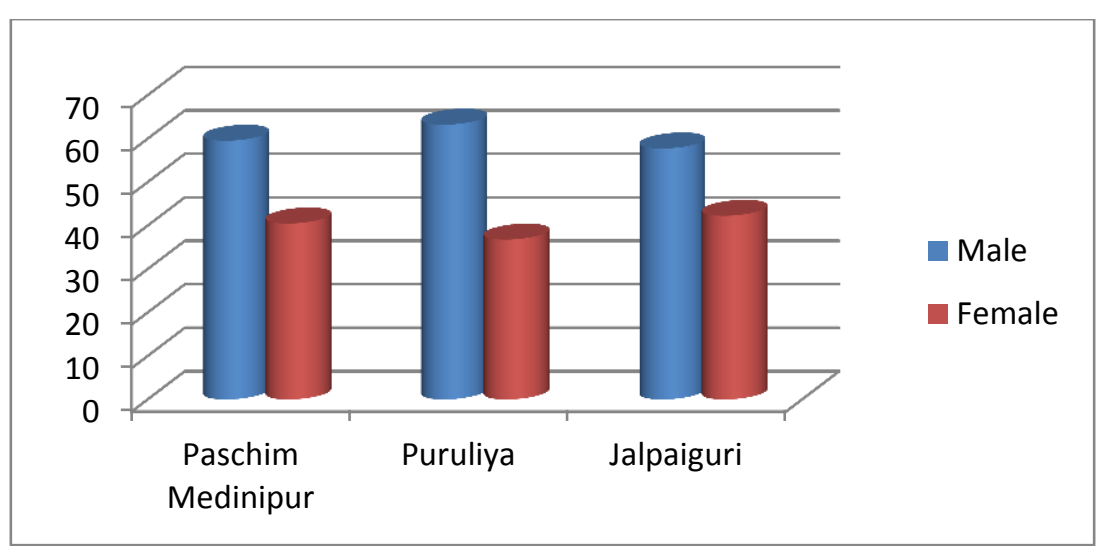

It is evident from table no 04. that gender social group of 'literates Male ST' under Puruliya $(63.22 \%)$ is greater than Paschim Medinipur (59.52\%) and Jalpaiguri (57.74\%) but social group of 'literates Female of ST' under 
Jalpaiguri (42.23\%) is greater than Paschim Medinipur (40.48\%) and Puruliya (36.78\%). Gender wise social group of in tribal percentage has been designing to the next diagram.

Table No. - 6: Gender wise social group of percentage in Tribal under Paschim Medinipur, puruliya and jalpaiguri districts.

\begin{tabular}{|l|l|l|l|l|}
\hline \multirow{2}{*}{ SI no. } & $\begin{array}{l}\text { Gender wise social } \\
\text { group }\end{array}$ & Percentage in Tribal \\
\cline { 2 - 5 } & & Paschim Medinipur & Puruliya & Jalpaiguri \\
\hline 1. & Male & 49.98 & 50.02 & 50.00 \\
\hline 2. & Female & 50.02 & 49.73 & 50.00 \\
\hline
\end{tabular}

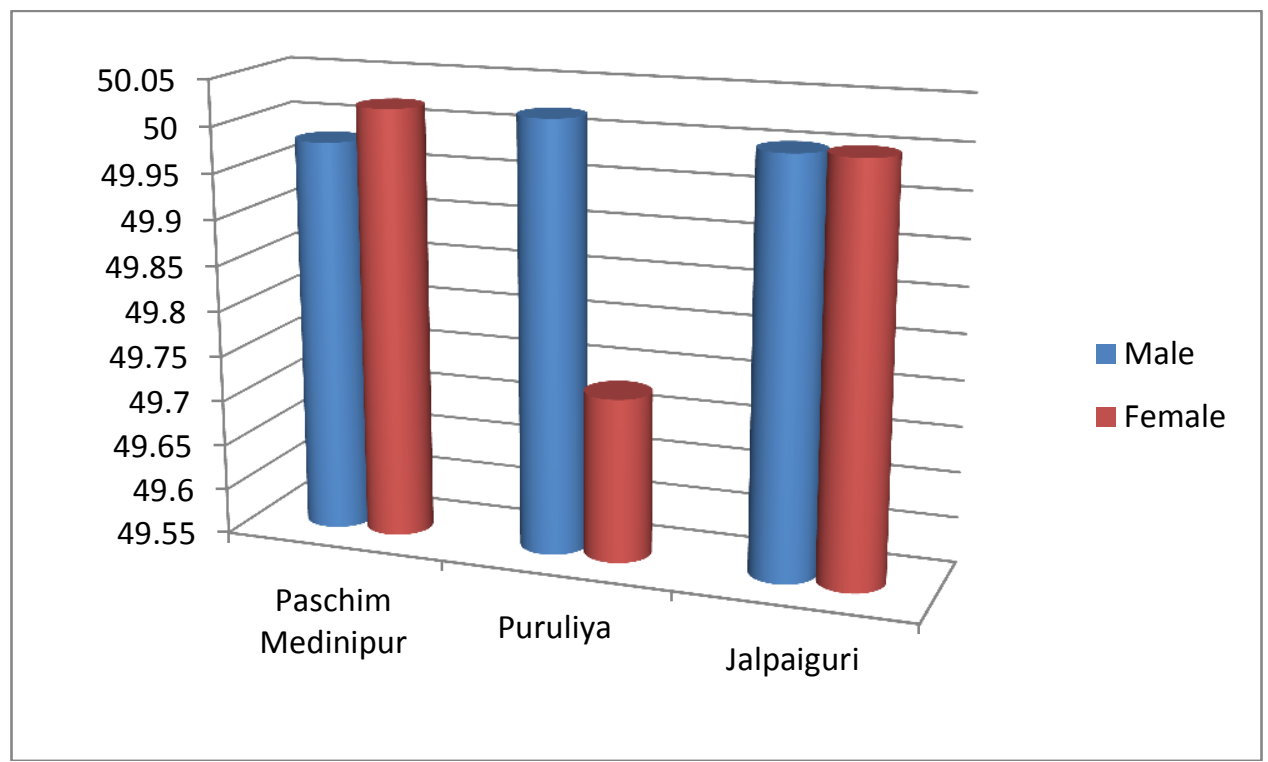

It is evident from table no 06. that gender wise social group of 'Male Tribal' under Paschim Medinipur (49.98\%), Jalpaiguri $(50.00 \%)$ and Puruliya $(50.02 \%)$ is same cross the line equal but 'Female Tribal' under Paschim Medinipur (50.02\%), Puruliya (49.73\%) and Jalpaiguri $(50.00 \%)$ is same cross the line. If we want to see feminine wise social group in percentage, we should look the next diagram.

Table No. - 7: Feminine wise social group of Tribal \& non-Tribal under Paschim Medinipur, puruliya, Jalpaiguri districts.

\begin{tabular}{|l|l|l|l|l|}
\hline \multirow{2}{*}{ SI no. } & Social group & Tribal and non-tribal in percentage. & \multicolumn{2}{l|}{} \\
\cline { 2 - 5 } & & Paschim Medinipur & Puruliya & Jalpaiguri \\
\hline 1. & Tribal Female & 51.02 & 48.73 & 48.52 \\
\hline 2. & Non-tribal Female & 50.02 & 49.73 & 50.00 \\
\hline
\end{tabular}




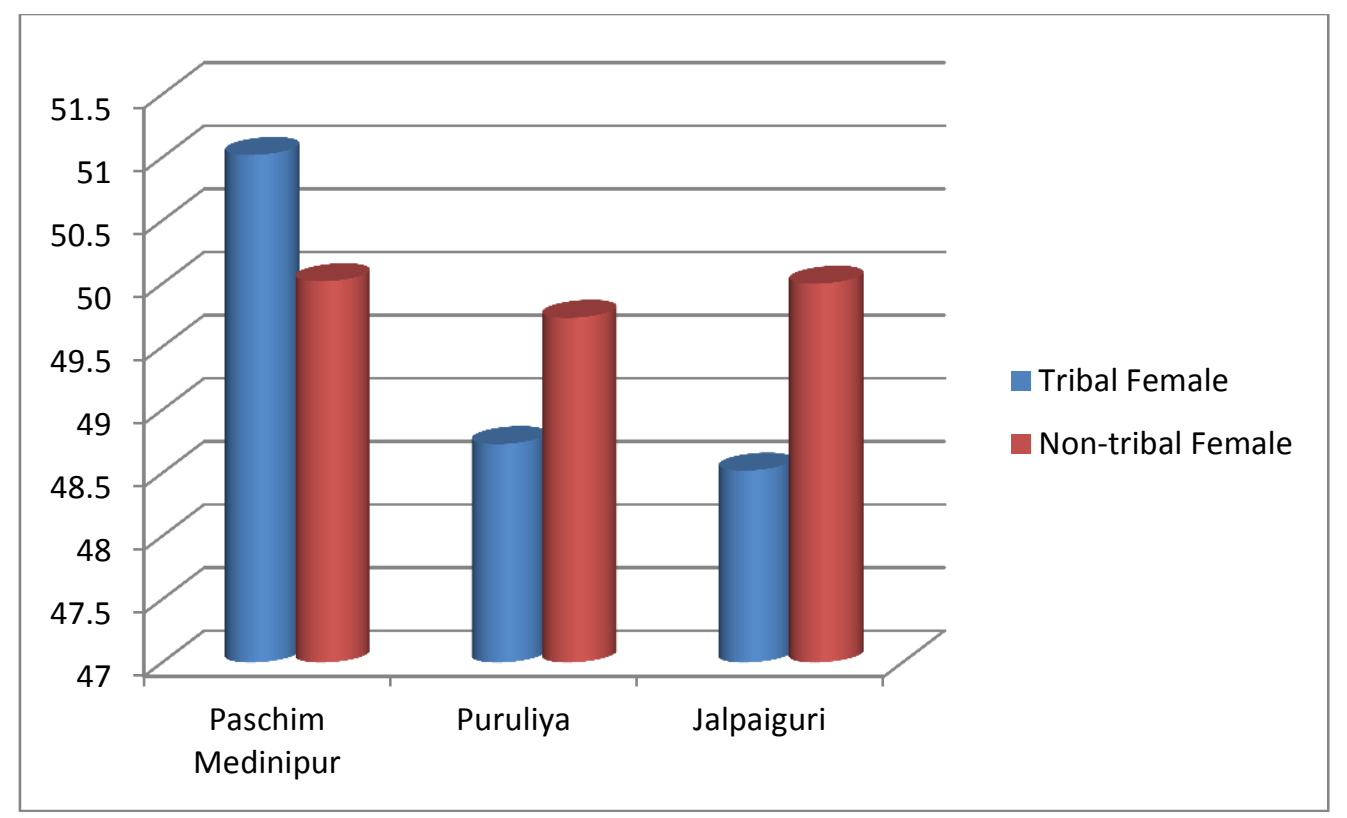

It is evident from table no 07. that Feminine wise social group of 'Tribal' under Paschim Medinipur (51.02\%) is greater than Puruliya (48.73\%) and Jalpaiguri (48.52\%) where social group of 'Non- Tribal' is under Paschim Medinipur (50.02\%), Puruliya (49.73\%) and Jalpaiguri (50.00\%) are same cross the line.

Census (2011) shows under these districts i.e. paschim Medinipur and Puruliya of population and literates of non-ST are highest in the district of paschim Medinipur but in percentage of population and percentage of lituates under the social group of ST and the highest in the district of Jalpaiguri and Puruliya, Gender wise social group of lituates male are highest in the district of puruliya and (female) in the district of paschim Medinipur. Gender wise social group of paschim Medinipur in non-tribal are same in male and female. Gender wise social group of lituates (ST) are highest as male in puruliya district and as female in Jalpaiguri. Gender wise social group of percentage in Tribal and Feminine wise social group Tribal and non-tribal are equal.

\section{Relevance of Present Research Work:}

To eradicate female illiterate, Education for tribal and non tribal women are an essential aspect of development. Education is a vital instrument to bring about a change in the cultural norms and patterns of life of the tribal women and to change their outlook and made them economically independent. It would help them to organize themselves to analyze their situations and living conditions and be aware of their rights and responsibilities. Education will enable them to take up jobs so that they can improve their situation. Social and economic status of the scheduled tribe to a large extent depends on the educational attainment. Educated women will be able to face the present day society better than earlier times. In the present context, no one can remain completely isolated, but they are influenced by the growth of modern society and culture. Government is providing a lot of support and grant for the education of tribal students. Tribal women are more important than non tribal women in any other social groups because tribal women are very hardworking and in almost all the tribal communities they participate in economic activities almost equally with men or works harder than men and the family economy and income also depend on women 


\section{Bibliography:-}

1. Bhowmick P.K. 1981 Rehabilitaion of a 'Denotified Community' the Ex-Criminal Lodhas of West Bengal. Royal Anthropological Institute Newsletter, 44: 6-8.

2. Bhowmick, P.K. 1963 The Lodhas of West Bengal. Kolkata: Institute of Social Research and Applied Anthropology (ISRAA).

3. Bhowmick P.K. 1985. Tribal Situation West Bengal, The Anthropologist, vol. 15, No.1, pp: 1-19.

4. Devi, M 1983. Lodhas of West Bengal-1. Economic and Politicall Weekly, 18(22), 947-949. Danda, A.K.2002. 'Predicaments of a marginalized community: The Lodha' Journal of Anthropological Survey of India. 51: 103111.

5. D'Souza, N. G 2003 "Indigenous education program case study empowerment and action: laya's work in tribal education"

6. Ghosh, A.K, 2007. 'The Gender Gap in Literacy and Education among the Scheduled Tribes in Jharkhand and West Bengal' in Sociological Bulletin, Vol. 56, No.1pp-109-125.

7. Mandal, H. Mukherjee, S. and Datta, A. 2002, West Bengal, in India: An Illustrated Atlas of Tribal World, Kolkata: Anthropological Survey of India, 32

8. Mete. J and Mandal. A. 2012, Profiling the Education among Scheduled Tribes in India, Golden Research Thoughts, 1(11), 1-4.

9. Mandal. A. and Mete. J. 2012, Tribal Development in India - Educational Perspective, Indian Streams Research Journal, 2(11), 2230-7850.

10. Mitra, A.1953. The Tribes and castes of West Bengal: Census 1951. Calcutta: Land and Land Revenue Department Govt. of West Bengal.

11. Panda. Sand Adak. A. 2014, 'Status of Women Self Help Groups Among the Lodhas of Daharpur village in Paschim (West)Medinipur, West Bengal, India: An Anthropological Perspective' International Journal of Interdisciplinary and Multidisciplinary Studies, Vol 1, No.3, 21-29.

12. Roy, A. (2008): Status of Human development in the District of Puruliya. Geographical Review of India. Vol. 70 (1): 85.

13. Singh, Kumar, Suresh. 1994 People of India: The Scheduled Tribes. Oxford University Press: Anthropological Survey of India.

14. Verma. R.C. 1990. Indian Tribes through the ages. Ministry of Information and Broadcasting Govt. of India. Web reference cited: censusindia.gov.in/2011-prov results/data files /mp/07Literacy.pdf accessed on 12.08.2014. 